\title{
DEVICE FOR MONITORING THE CONDITION OF THE NATURAL BACKGROUND
}

\author{
Nikolay Nenov \\ Technical University Gabrovo, Bulgaria, Depatament of Managment \\ №4, H. Dimitar Str., 5300, Gabrowo, Bulgaria \\ Ph.: +(359)66827481, e-mail: nenovtugabrovo@gmail.com
}

\begin{abstract}
Life on Earth arose and exists in terms of natural ionizing radiation. Environmental pollution with radioactive substances begins with the emergence of the nuclear industry. Proceeding from the accepted truth that there is no safe dose of exposure to radioactive radiation and accumulated over the years experience (more than 25 years), the author of this article provides an apparatus for monitoring the condition of the natural radiation background based on light and sound indication in all cases when there is increase toward "imperturbable" atmosphere.
\end{abstract}

Keywords: radiation, gamma rays, beta particles, nuclear power.

\section{Introduction}

In recent years it became clear that the development of mankind is closely associated with more large-scale use of nuclear energy (Fig. 1). A striking example of this is the start of a program for building the world's first fusion power plant.

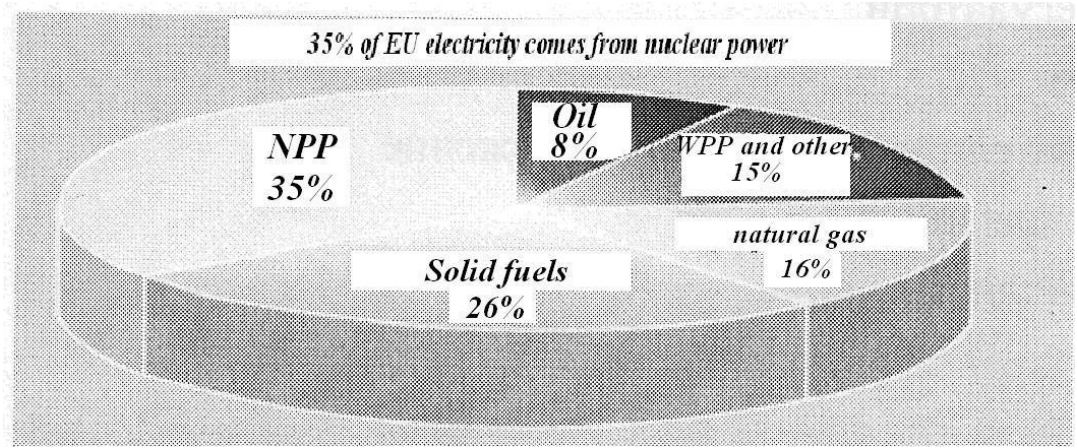

Fig. 1.

At the same time, however, accidents at nuclear power plants (NPP) in Fukushima and Chernobyl have led humanity to think seriously on the safe operation of existing and future NPPs. For many years also showed that the safe dose of radiation does not exist. Therefore, creating an opportunity for preventive control of the state of the natural radiation background (NRB) would contribute to warning of the danger of radioactive contamination with all ensuing consequences. In this regard, it was developed signaling apparatus - indicator of radioactivity, which allows control of the state of NRB.

\section{Exhibition}

The indicator of radioactivity is a device that reports the number of pulses per minute, generated by gamma or beta rays. Appearance of the device is shown in Fig. 2.

The number of pulses per minute is recorded in a file in the embedded memory card, and then the data can be viewed and displayed on a computer. If the computer is plugged into the Internet, it is possible to examine data from the entire network. 
Simultaneously, the LED display shows the current radiation. Optionally it can include acoustic signal indication. The device can work with external power supply (from an adapter or USB) and battery (2xAA).

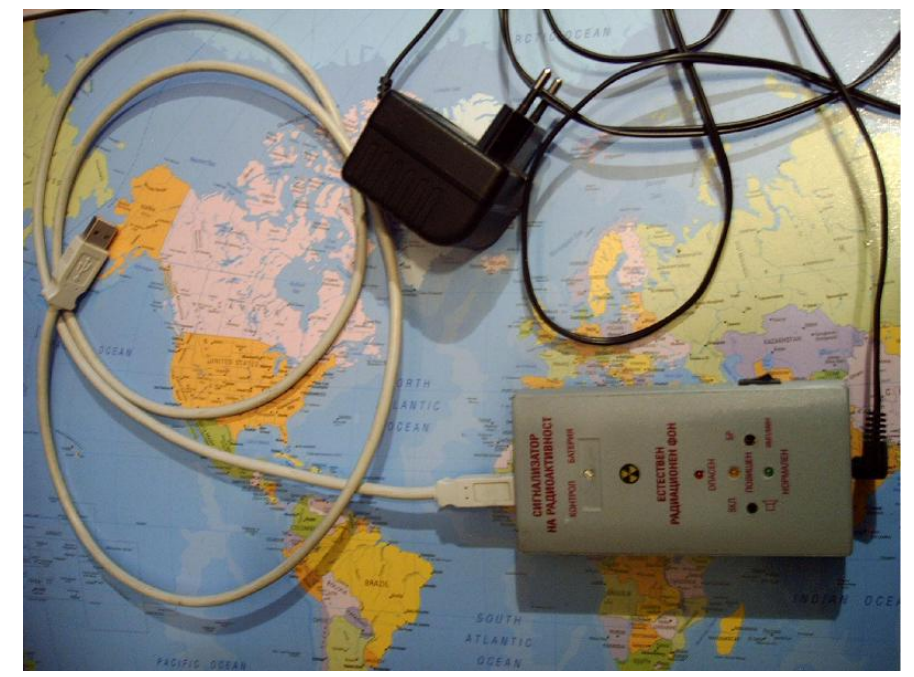

Fig. 2.

Block diagram of the device is shown in Fig. 3.

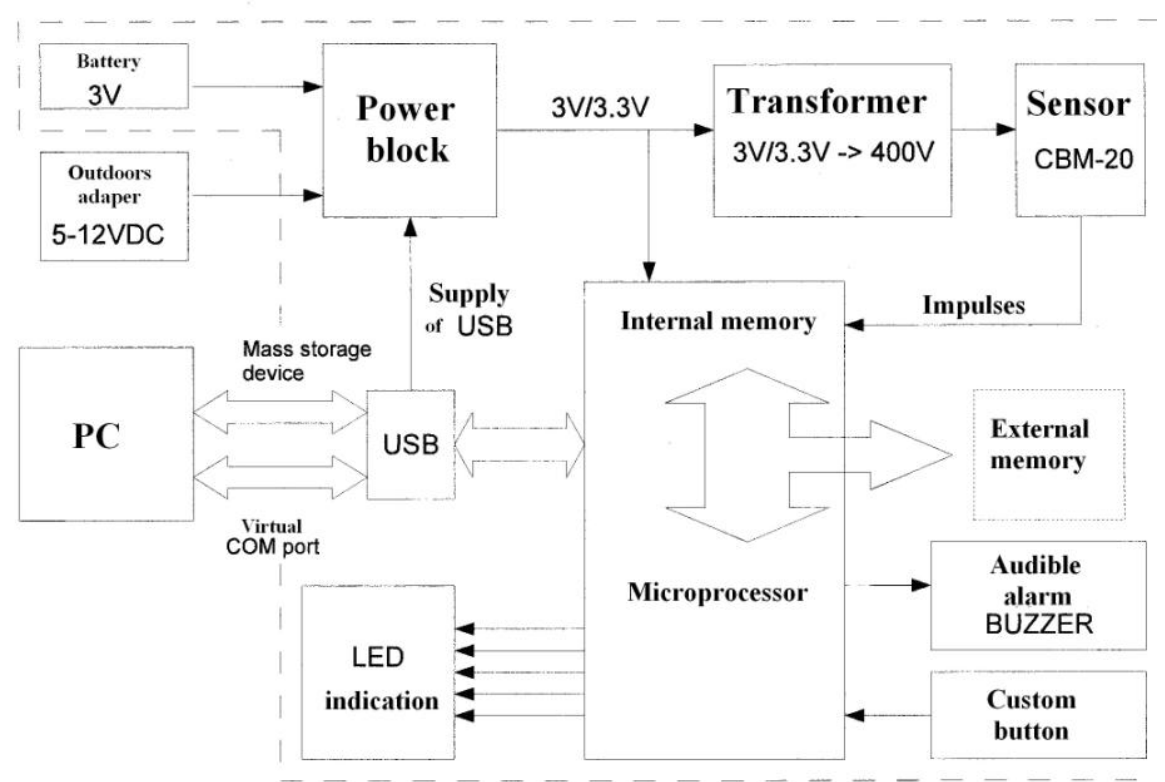

Fig. 3.

When the device is turned on it is desirable the user to set time: set the device in the USB and wait to install the drivers for the Mass Storage Device (this happens only when the board is included for the first time on a computer). If everything is successful will appear new Removable disk in My Computer, i.e. device behaves like a USB flash memory. This memory will find other drivers to be installed. If Windows asks for drivers, then it is identified those in the newly device. After installing all the drivers it will have to show a new virtual COM port on your computer. Trough this COM port can be made settings and to examine in real time when it enters each pulse. Access to the device through this port can be done with any terminal program. In our case we use the built in Windows "Hyper Terminal". Start the Hyper Terminal and select the appropriate number of COM port - settings are $192008 \mathrm{~N} 1$. The 
default password for entering the menu is "pass". When writing "pass" a menu will appear. First item of this menu is setup time. Select "1" and then press Enter to follow the prompts. When the time is properly entered it will be written "TIME is SET successfully".

At any time, the terminal can be observed when in the time arrives each pulse and how many pulses per minute. All information can be saved to a file on your computer if you choose Capture Text feature of Hyper Terminal from the menu Transfer.

Device always shows the number of pulses for the last minute by the LED, but does not record data, unless expressly asked by the user. Start recording data in memory after it is pressed and hold START / STOP button for more than 2 seconds. Short ( 0.5 seconds) beep will confirm that the application is accepted. In this situation becomes the following: it is created a new file name that corresponds to the time in which we pressed the button, i.e. the file name displayed when starting from the data entry. For example, if the button START / STOP is pressed in 21 hours and 34 minutes of 08 September, it will have a file name: 09082134.TXT. 09 is September, 08 is the date, 21 is the hours and 34 are minutes. From that time on will record the data on the number of pulses in each minute. New data in this file do not appear every minute and every hour. This is done to not write too often memory. However, the user at any time (but it should be past 1 minute from the creation of a file to be at least 1 outcome) may terminate and see the recorded results to date if press and hold START / STOP button for more than 2 seconds. Then, if there is data in the buffer, it is recorded and the current file is closed. The time of closing the file is the final time, which lasted until measurement. It is recorded in the file properties - visible if you right-click the file, select Properties - Modified field. So the file name will show the time in which the measurement started and Modified field from the file properties will show the final time of measurement. Once the current file is closed, the device continues to count pulses and to visualize the terminal program and through the LED, but not record them. If the user wants to record data once he has closed the file must again press and hold START / STOP button (at least for 2 seconds) to open a new file for writing.

Display results: the results in the file are arranged in columns, i.e. have the separator character for space and new line. There are many programs and ways to visualize data. The text file can be opened with Open Office Calc. Results will be arranged in the first column. Thus can exploit the potential of various programs for drawing diagrams and graphs in the desired form with the data from the menu (Fig. 4)

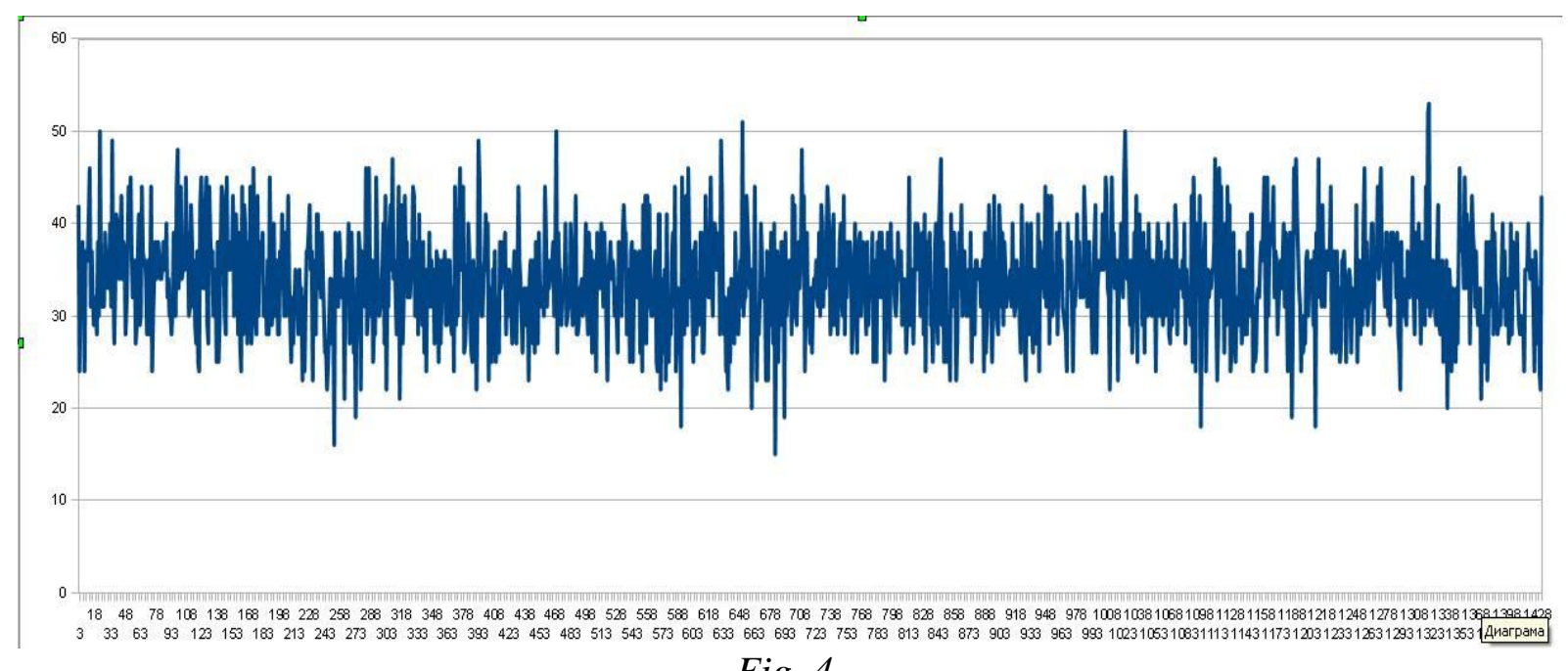

Fig. 4. 


\section{Conclusion}

The developed indicator has a new principle, and allows anyone wishing to inquire about the state of its surroundings in terms of additional sources of radioactivity. When you turn the indicator to a computer it can draw information on the natural radiation background from another computer located at an arbitrary distance from the control site. For people with high interest accumulated in the memory data can be processed with the help of appropriate software to obtain the necessary results for different periods of time.

\section{References}

1. Ванков И.Д., В.Кр.Златаров. Ядрена електроника. София, , 1980.

2. Дмитриев А.Б. и др., Приборы и техника эксперимента, №5. Москва, Машиностроене, 1967.

3. Митров Г.Г., и др. Радиологична техника и льчезащита. София, Техника, 1968.

4. Мишев И.Т. Основи на съвременната радиационна дозиметрия, София, Техника, 1971.

5. Ненов Николай, Интелигентна система за фонов мониторинг, Известия на ТУ - Габрово, 2010

6. Пугачев А.В., Э.В. Сахаров. Справочник по радио-изотопной автоматике. Москва, Енергия, 1974.

7. Черняев А.П. Взаимодействие йонизирующего излучения с веществом. Москва, Физматлит, 2004. 